\section{BANGKOK MORPHOLOGY AND ITS OLD SETTLEMENTS : AN OVERVIEW}

\section{Kamthorn Kulachol $^{1}$}

\begin{abstract}
This article outlines the physical development of Bangkok since its founding as a capital city 220 years ago, with an emphasis on its old settlements known as the Rattanakosin area.
\end{abstract}

Between 1534-1546 A.D. of the Ayuthaya Period, a small village named Bangkok, located by the Chao Praya river, assumed a new role as a check point for ships passing to and from the capital city. After the fall of Ayuthaya in 1767 and Thonburi in 1782, King Rama I, the founder of theChakri dynasty, started building a new capital named Rattanakosin.

King Rama I deliberately built Rattanakosin, or new Bangkok in a manner reminiscent of Ayuthaya as manifested in its city plan, architectural style and even the names of significant places. The newly built walled city consisted of the inner core, where the king and aristocrats lived and the outer city, where their children settled near market places, temples and sprawling communities of diverse racial groups.

Mixed settlements within the city walls became overcrowded towards the end

\footnotetext{
'Associate Professor, Department of Urban Design and Planning, Faculty of Architecture, Silpakorn University, Bangkok
}

of King Rama III's reign in 1851. Throughout the first 70 years of development people preferred to live and travel on water rather than on land, and canal connections in and around the city were a necessity. Such a lifestyle had impressed visitors from abroad, and Bangkok was then widely known as Venice of the East.

The reigns of King Rama IV - King Rama VI (from the mid $19^{\text {th }}$ century to the first quarter of the $20^{\text {th }}$ century) saw radical changes in all walks of life when the nation faced the strong impact of imperialism and the industrial revolution from the West that soon overshadowed the long predominant Chinese and Indian influences. The demolishing of city walls to extend the city limits, the construction of the first roads, and the emerging landbased settlements are only a few examples. Bangkok turned 100 years old during King Rama V's reigns, and by that time its image was transformed to look like a European city with grand boulevards, bridges, plazas, and buildings in neo-classic forms. City beautification and pro-Western policies prevailed until the First World War and beyond. While more and more roads were constructed, fewer canals were left to be seen. After the end of King Rama VI's reign, a huge number of new settlers from the provinces flocked to the outskirts of Bangkok.

Only two months before relinquishing absolute power to the people, King Rama VII presided over the grand opening of the first bridge ever built for automobiles across the Chao Praya river in April 1932 to celebrate Bangkok's $150^{\text {th }}$ anniversary. About a decade later, towards the end of the Second World War.General Plaek Piboonsongkram and his government decided to build the 
Democracy Monument, surrounded by the renewed image of Ratchadamnoen Avenue, to represent a democratic and modern society.

Just a decade or two after the end of the war, Bangkok grew into a metropolis and continued to expand without direction and adequate control, which resulted in the present chaotic situation. Some critical issues in city planning are subsequently discussed by the author.

Efforts to preserve Bangkok's old settlements, the area once confined within the city walls, took shape in 1971 . The government has put a tight restriction on any developments within the inner part where the Grand Palace, the Temple of the Emerald Buddha, and other precious historic buildings and sites are located. However, a negative policy to control developments in the outer part where most people live and work has failed to improve social, economic and physical environments because people have kept moving out, business investments have been dwindling, and long established communities have lost their identities and finally turned into slums. The failure was caused partly by the disregard of public participation and missing stakeholders in the planning process. Recent studies by university scholars suggest that in order to revive the presently decaying old settlements and bring back the quality of life, a humanistic approach with positive guidelines is needed.

\section{Preamble}

After 220 years, the story of how Bangkok has been shaped should be disseminated once again so that the present generation can know this centuries-old city better. It is also the right time for the general public to update their knowledge, especially those who are concerned with or interested in the city's physical development.

Most of the writing below is more or less a revised edition of the article entitled Physical Development of Bangkok City Since Its Inception up to 1932 by the author himself and his co-author, Songsan Nilkamhaeng of the National Archives, in Thai language to commemorate Bangkok's bicentennial about two decades ago (Kamthorn and Songsan,1982:221-244). However, the present version which is rewritten in English for the first time provides a more humanistic approach than the previous one.

\section{Historical Background}

It is essential for the readers who know very little about Thailand to grasp its historical perspective prior to the founding of the Chakri Dynasty and the concurrent promulgation of Bangkok, or Rattanakosin, as the new capital city of Siam.

The following chronology is , therefore, provided to serve as an outline for the readers to refer to while pursuing stages of the city's development:

$\begin{array}{ll}\text { SUKHOTHAI Period } & 13^{\text {th }} \text { century } \\ & \text { A.D. lasted for } \\ & \text { about } 200 \text { years } \\ \text { AYUTHAYA Period } & 1300 \text { s }-1700 \text { s } \\ & \text { A.D. reigned } \\ & \text { for more than } \\ & 400 \text { years }\end{array}$

THONBURI Period from 1767 to 1782 RATTANAKOSIN Period (Chakri Dynasty)

1782 - 1851 King Rama I - King Rama III 1851 - 1925 King Rama IV-King Rama VI 1925 - 1932King Rama VII 
1932 - Present Constitutional Monarchy 1946 - Present King Rama IX

This article about the evolution of physical form begins with the late Ayuthaya period, a time contemporaneous with Europe's Baroque, and ends in the twentieth century, with an emphasis on the old Bangkok area where the quality of life and sense of community are on the brink of decline.

\section{The First Settlements}

Bangkok, presumably derived from Bangkoh or island, originated from a district of orchards and agricultural land amidst scattered villages. The district became well known during the late Ayuthaya period, approximately by the first half of the $16^{\text {th }}$ century, when a number of the river bends were cut short at the king's command to save travel time from the gulf up to the capital city. With a new shortcut running straight through the middle of Bangkok district, the Chao Praya river changed its course, thus splitting the land into two sides: Thonburi on the west and Bangkok on the east. As a result, the former river with its curves turned into canals along which boathouses and water-based activities gathered on both sides. For more than 200 years, the new role of Bangkok as a checkpoint for ships to undergo inspections and pay customs duties prevailed until the end of the Ayuthaya period.

It was in the same year, after the fall of Ayuthaya in 1767 , that King Taksin reclaimed the nation's independence from the Burmese, and chose Thonburi was chosen as the site of his new capital.

\section{Originated from the West Side}

The capital city of Thonburi in fact covered both sides of the Chao Praya river though almost all palaces, institutional buildings, temples, prisons, commercial and residential areas were concentrated on the west side. On the opposite side of the river, minority settlements and agricultural fields were scattered on wetlands - a perfect strategic place to slow down enemies if they were ever to attack from the east.

Surrounded by city walls on both sides of the river, the new capital of Thonburi was indeed designed as a volatile city with the main waterway running from the north to south through its heart. While King Taksin's reign lasted only 15 years, some prominent buildings such as the Temple of Dawn and the King's palace, now occupied by the Royal Navy, remain as major tourist attractions.

\section{Extending to the East across the River}

It is widely known that King Rama I, who established the Chakri Dynasty after his ascension to the throne in 1782 , started to build the city of Bangkok as a new capital on the opposite side of the Chao Praya River in 1783 gave it the name Rattanakosin or Place to Keep Precious Stones.

It is believed that there were three main reasons for locating the new capital on the east side of the river (Naengnoi et. al, 1991:18):

\section{- Potential to build new city walls}

Open fields on the east side were easier for moat digging parallel to the 
enlarged city walls than the dense by populated area on the west.

\section{-Difficulty in fighting against erosion}

Being washed by tides from the north, the banks on the west side eroded quickly.

\section{- Problem for future expansion}

The Land within the old city was mostly occupied and the palaces were flanked by the main temples. It was almost impossible to build greater palaces or to extend the city's boundaries.

King Rama I spent most of his lifetime as a warrior fighting great wars with neighboring countries. During his younger years, he had witnessed the glory of the old capital of Ayuthaya until the day of its destruction by the Burmese in 1767. It is, therefore, natural that when he had a chance to rebuild the capital city, it could be nothing but the new Ayuthaya.

So the first significant buildings on the east side of the Chao Praya river included the Grand Palace and the Temple of the Emerald Buddha complex for the King and his brother's palace in the north now functioning as the National Museum. Apart from these temporary buildings which were constructed with timber in a hasty manner, the king also laid the foundation stone of the City Pillar right at the corner of the Temple of the Emerald Buddha in order to inaugurate the new capital. Most of the land for building the Grand Palace complex had been taken from a Chinese estate at the king's command. Chinese squatters were then relocated to a new site just outside the city walls, south of the river while the settlements of other ethnic minorities namely Vietnamese,
Cambodian, Laotian, Mon, Malaysian, etc. were dispersed to the outskirts of the city.

\section{Development in the First 70 Years}

Since Bangkok is more widely used than Rattanakosin, let us hereafter refer to it by the former name although contemporary Thai people prefer Krungthep, the initial word preceding its official and lengthy name. ${ }^{2}$

Bangkok was first built with surrounding walls for protection against enemies, mainly from the east while the river served as a natural border on the opposite side. After the old city walls were demolished to pave way for the city's expansion, new walls were erected together with encircling moats, constituting a total area of 4.14 square kilometers (about 1,024 acres), approximately $1.8 \mathrm{sq} . \mathrm{km}$. as the inner part and $2.3 \mathrm{sq} . \mathrm{km}$. as the outer part.

The first celebration making the founding of the new city took place in 1785 , three years after its inception. When the first five years had passed without wars, the rate of urbanization increased very rapidly. According to British ambassador John Crawfurd and preacher Jacob Tomlin, it was estimated that Bangkok's population in the 1820 s ranged from $50,000-80,000$, more than half of whom were Chinese immigrants mixed with

${ }^{2}$ The full name of Bangkok as the capital city is: Krungthep Mahanakorn Amorn Rattanakosin Mahindrayuthaya Maha dilokpop Noparatana Ratchathani burirom Udomratchanivet Mahastarn Amornpimarn Awatansatid Sakkatattiya Visanukamaprasit. 
diverse minority groups from neighboring nationalities (Naengnoi and et.al, 1991:78).

As illustrated, the city plan during the reigns of King Rama I - King Rama III by the mid $19^{\text {th }}$ century looks like a bow with the old moat running in the middle parallel to the east city walls, holding them together by two straight ditches. The land was therefore divided into two big chunks; on the left was the inner area and on the right was the outer area, divided into three equal subdivisions.

Most of the land in the inner area was dedicated to palaces, temples, aristocrats' properties, as well as military and administrative functions. Residential uses were hardly found because people at that time preferred to live in boathouses along the waterways. There was also an open space next to the Grand Palace to be used as a cremation ground exclusively for members of the royal family.

A memo written by a French cardinal reveals that the early kings of the Chakri Dynasty determined to have their palaces and temples built after the forms and names of many classic structures of the Ayuthaya period. Builders with superb skills and workmanship who survived the destruction of Ayuthaya were recruited to create top-class architecture for Bangkok. The cardinal's admiration for such magnificent architecture, standing in contrast to the fresh natural environment, is seen as a result of King Rama II's and Rama III's efforts to the restore, decorate, and refine countless imperial buildings throughout the city.

Not only in architecture did Bangkok try to follow the model of Ayuthaya, but also the way its city plan was organized. For example, the main palaces with inner walls were situated next to the river; foreign settlements were located outside the city walls to the south of the Grand Palace; a golden stupa was built on top of an earthen mound as the city's landmark; and a canal of the same name was dug just outside the city wall to serve as an arena for water festivals. For transportation, waterways, especially canals, were necessary for the people at that time because boats and rafts were major modes of travel that made business and trade possible while land transportation was infrequent and limited to pedestrian traffic only. There were only a few streets linking the Grand Palace to the main gates of the city.

Since the kings and nobles were polygamists, they had to provide many palaces for their children. That is why the land gained for the city's expansion was mostly occupied by spillover palaces and residences for family members of the aristocrats, accompanied by settlements of the immigrants and slaves who served them. Neighborhoods and communities were built around market places and temples patronized by the nobles in the outer area of the city. There was also a dominant public open space at the center of the outer area, marked by a giant swing in front of a significant Buddhist temple and the Brahmans' monastery. The open space with the giant swing built for religious purposes now faces the present city hall in the north and the temple in the south. This ceremonial space was used by all city dwellers.

The first 70 years of Bangkok's history ended as King Rama IV ascended to the throne in 1851 . The walled city where 
public utilities were not available reached a transitional period with the need for another extension of the city limits to meet the demands of an increasing urban population.

\section{The Era of Western Infiltration}

Like all other capital cities in Southeast Asia, Bangkok by the late 1850 s could hardly resist the influx of western cultures and the overwhelming impact of the industrial revolution. King Rama IV, or King Mongkut, whose image has been portrayed in the world- renowned play The King and I, had to succumb to the western powers and let their influence penetrate the Thai society.

By 1854 , the population of Bangkok has mounted to about 400,000 and hence the city had to face the problem of overcrowding. King Rama IV finally decided to disassemble the city walls and annex another 2.4 square kilometers (almost 600 acres) as appeared in the new city map. A third encircling moat parallel to the old ones, lined with seven distant forts but without walls between them, emerged to mark the new boundary. However, it is interesting to note that it took more than two centuries for Bangkok to abandon the city walls which lad characterized European baroque cities.

It was mentioned earlier that most Bangkok city dwellers in the first 70 years spent their lives doing business, traveling, and living on waterways. According to memos written by European immigrants, it was the thousands of boathouses, rafts and the network of canals connection throughout the city that made Bangkok better known as the Venice of the East. Unfortunately, such an image started to degenerate when a few roads for land transportation as well as land settlements took place for the first time in the second half of the $19^{\text {th }}$ century, during the reign of King Rama IV.

Once the door was wide open to Westerners, it was considered normal practice for the ruling monarch to hire as many as 84 professionals and experts from Europe and the United States to assume consultants' or civil servants' roles, not mentioning an even greater number of those involved in trade and business in the private sector.

These Westerners, with their modern ways of doing business, began to settle next to the districts where the Chinese community had settled and dominated trade with the local people for a long time.

The southern areas of Bangkok, previously developed outside the city walls, now became places of hustle and bustle in the middle of the city where offices, trading companies and warehouses of both Chinese and Europeans stood side by side near embassies and consular offices. These developments were first packed on the riverside but later scattered along both sides of the main roads - the roads that were built later to satisfy complaints that the lack of such facilities for promenading or horse riding was hazardous to health.

King Rama IV approved the construction of the first three major roads of Bangkok: the New Road stretching from the grand palace to the communities down south of the river, the Bamrung Muang Road extending the main pedestrian street from the giant swing eastward (now Rama I Road) 
parallel to the main canal that links the city to the countryside, and the Fueng Nakon Road traversing the first two, across the middle of the city in a north south direction.

It should be noted that never before in the early history of Bangkok had land settlement and land transportation, particularly roads for vehicles, materialized until 80 years after its founding. In terms of physical character, modern offices in European neoclassical style and Chinese shophouses in Singaporean style began to emerge and gradually gained popularity.

Furthermore, the construction of King Rama IV's Summer Palace on the bank of the canal in a suburb has set a new direction for the city's expansion to the east in the following years while areas in the north were still quiet with sparse settlements gathering around a few Buddhist temples.

\section{Time for Beautification and Modernization}

After succeeding his father in 1868 , King Rama V ruled for 42 years. He has become the most beloved monarch because of the significant changes he brought to the country and his subjects. $\mathrm{He}$ is particularly respected for saving the nation from being colonized by the Western powers, eradicating slavery, modernizing infrastructures and introducing a plan to the city beautification. Under the ingenious king's leadership, Bangkok, when close to 100 years old, was fully equipped with western-standard systems: economic, education, public health, industrial, public welfare, transportation, military, administration, telecommunications, business, etc.
The reign of King Rama V witnessed many new inventions, such as steam ships, automobiles, railroads, trams, electricity, telephone, telegraph, radio broadcasting, and so on. These helped to add modernize the capital city. As a result, the population of Bangkok soared to approximately 600,000 in $1900^{3}$ while the total urbanized area covered 13.33 sq.km., about three times larger than the walled city of the mid $19^{\text {th }}$ century.

With the fast growing rate of urbanization and the proliferation of Western influence, King Rama V was keen to facilitate movement inside the city with an extensive transportation network and infrastructure, especially roads inside the inner core and canals connecting to the suburbs and other remote areas. By that time, boathouses and rafts had lost their popularity due to damage caused by steam ships while land subdivision and land speculation as well as the importation of automobiles in 1902 assumed leading roles and induced changes in the economic system.

Towards the end of the $19^{\text {th }}$ century, King Rama V, following in his father's footsteps, bought a large piece of land in the north and built the Dusit Palace Complex for himself and his family. The new palaces were a new magnet setting the new direction for the city's expansion to the north. It did not take very long for the areas around the palaces to be developed as a high-class, low-density residential zone.

Back in 1897, King Rama V visited Russia, Germany, France, England and

\footnotetext{
${ }^{3}$ From official statistics of the Census Division, Department of Administration, Ministry of Interior.
} 
other countries in Europe. Upon returning home, he planned to link the Dusit Palace to the Grand Palace with a boulevard, like Unter den Linden in Berlin or The Mall in London. Two years later, Ratchadamnoen Avenue, meaning the royal path, was actually built between 1899-1903. Three connecting parts constitute the whole length: the first one lies outside the old city walls while the second and the third parts cut through the old settlements. As shown in the illustration, the avenue clearly dominates the old city plan with its geometric supremacy.

For the local people, such a beautiful city design was a real shock. While pavements neatly lined with trees, western-style street furniture and embellished bridges were much admired, everybody was suspicious of their intended functions since the whole avenue upon completion was underused and left empty - only a few rickshaws and pedestrians came into sight once in a while.

A public square called the Royal Plaza at the north end of Ratchadamnoen Avenue was another feature designed to accentuate the Dusit Palace Complex. When King Rama V perished in 1910 , his equestrian statue was raised right at the center of the square, serving as a terminating point in the same manner as King Louis XIV's statue in front of Versailles in Paris. The Royal Plaza thus symbolizes the glory of the great monarch, baroque traditions, and the City Beautiful image.

The succeeding reign lasted for only 15 years. Despite hard times during the first world war, King Rama VI had completed a number of unfinished projects initiated by his father, namely the construction of palaces within the Dusit Complex, the first railroad terminal, Hua Lampong, the first railway bridge across the river, Rama VI bridge, and Chulalongkorn University. For his own initiative, the first public park located on Rama IV road, Lumbhini park, was dedicated to the capital city.

The pro-Western tradition, in terms of social values, architectural style and urban way of life, continued until the end of the reign of King Rama VI in 1925. It can be concluded that for 74 years, throughout the reign of King Rama IV to King Rama VI, the city underwent tremendous changes and more and more contrasts became evident between the new outer areas and the old inner areas of Bangkok.

Generally speaking, the outer areas have been developed mainly for the facilities and utilities of a modern city such as educational institutions, railway station, and mixed residential-commercial shophouses. The areas settled by Westerners expanded further and turned residential neighborhoods into an international financial business district now known as Suriwong-SilomSathorn. On the other hand, the old inner area became more densely populated after the First World War with increased commercial activity. Many residents inherited property from their forefathers. Interestingly, quite a number of the new settlers used to be slaves who lived and served their masters in the vicinity.

\section{Regime Change and World War II}

King Rama VII's reign started in 1925 but he sacrificed his throne soon after Bangkok celebrated its $150^{\text {th }}$ anniversary to pave the way for the 
democratic system in 1932. And to commemorate such an auspicious occasion, the roads on both sides of the river were linked together for the first time when the Prabuddhayodfa bridge the first bridge, ever built for automobiles, was inaugurated together with the monument of King Rama I by King Rama VII himself.

After the regime change, from absolute monarchy to democracy, in 1932, there was a series of coups d'etat by top military brass. However, the urbanization rate of Bangkok kept growing continuously and land in the outer areas was densely occupied by new immigrants from the provinces.

In 1939 , the year that the Nazis invaded France, the city of Bangkok underwent a major operation when all of the fully mature and shady mahogany in the middle of Ratchadamnoen Avenue were felled to make way for the construction of a Democracy Monument together with uniform buildings on both sides throughout its length. It was a strong will of the then Prime Minister who was a major coup leader, General Plaek Piboonsongkram, to show the modernity of Bangkok as well as the rise of the democratic system in Thailand. Borrowing the image of the Arc de Triomphe and the Champs-Élysées in Paris, the new face of Ratchadamnoen Avenue was completed and ready for celebration in 1943, two years before the end of the Second World War. The image of a Western boulevard with a grand monument in the middle has brought a reputation and pride to Bangkok dwellers and Thai people in general without regard to the sharp contrast and incongruity with its surroundings.

\section{Growth in the Second Half of the $20^{\text {th }}$ Century}

Bangkok was fortunate never to have been attacked or damaged by any wars throughout the 220 years of its existence. Yet the city exploded into an unrestrained metropolis with a multimillion population after the Second World War. In modern-day city planners' view, the gap between the capital city and the rest of the country has widened since 1932 because Bangkok has already become the center for international trade and investment, education, health care, job opportunities and better living standards (DTP, 1999:111). It is incredible that with a population of nearly ten million and an area covering little more than $1,500 \mathrm{sq} . \mathrm{km}$. the city still keeps on growing recklessly without adequate control and efficient public services.

Without an articulate and widely recognized master plan or accepted guidelines, decisions to define land use and to create a transportation network for Bangkok have been arbitrarily made by politicians and government officials as well as the private sector, particularly developers and land owners, throughout the last five decades of development. A broader picture of the city can then be described as chaotic and lacking of a clear vision to cope with present and future problems efficiently.

The following commentaries more or less reflect the physical changes of greater Bangkok in the last 50 years:

\section{Waterways were replaced with roads}

Apart from causing eventual area-wide flooding in the flood prone sites of the 
city, the beautiful canals that once earned Bangkok the name Venice of the East are gone forever and were replaced with either a heated concrete surface or polluted open drainage.

\section{Lack of land use planning and controls}

Bangkok has proved that it gained nothing from overcrowding. Not only does it have inadequate open spaces and innumerable slums, but also high-rise buildings scattered all around the city. Furthermore, the real estate business has grown rapidly at the cost of public investment, not to mention the concentric development pattern that has become the main obstacle to providing effective and efficient infrastructure.

\section{Lack of integrated transport systems}

Bangkok was and still is infamous for its traffic jams due to a lack of systematic planning for transportation. Roads were built in such a way that resulted in superblocks and overwhelming traffic problems. In addition, relying heavily on buses as the only answer to mass transportation needs plus delays in the decision-making process to solve critical problems such as railroad on-grade crossings have worsened the situation. Mass transit investments have only begun and are yet to expand. And worst of all, costly construction of expressways, overpasses, underpasses, etc. has encouraged the increase of car ownership. As for water transportation, which had been overlooked for a long time, express boats along the river and main canals have played only an insignificant role due to inadequate support and poor management. In the broader picture, most of the governments' decisions in the past were made too late to gain an efficient mass transit system and restrict the use of private automobiles.

\section{Lack of public understanding/ concern}

Except for a handful of scholars and professionals, the rest of Thai society, including politicians and most decision makers, hardly understand what city planning is all about and how it could enhance the quality of life of city dwellers. Quite a number of people in Bangkok still suffer from living next door to toxic plants or slaughterhouses. Such an example shows that a number of master plans prepared by experts, both domestic and international, have never been implemented seriously.

\section{Lack of efficient tools}

There are no effective laws or zoning ordinance available. The existing 1975 City Planning Act and the obsolete Building Code are too general and not nearly powerful enough to cope with the city's ever growing problems. In other words, law enforcement to set order to the city and protect its citizens' right is not adequate.

It is simply justified to conclude that the physical form of Bangkok during the first 70 years of development was better structured than in the later periods. Overcrowding, lack of thoughtful planning and weak controls are the key factors involved in the reduction of quality of the built environment and hence the livability of the city today. However, with the initiative of a conservationist group some 30 years ago, the government has been persuaded to preserve the areas of the city's origin. 


\section{Preservation of the old city}

The first idea of preserving the old city of Bangkok or the Rattanakosin Area came up in 1971 to celebrate the $25^{\text {th }}$ anniversary of the present King's ascension to the throne. The proposed scheme is well known as the Rattanakosin Island Project. Its main objective is to safeguard the worldrenowned architectural gems inside the Grand Palace, Temple of Emerald Buddha, and countless monuments and sites of historic significance built on both sides of Chao Praya River within the old city boundaries.

Ironically, a major construction project, the Pra Pinklao bridge, took place in the very same year with the very same objective. Upon its completion in 1973, the bridge has challenged the preservation aims by attracting a huge amount of traffic to and from the central part of Ratchadamnoen Avenue. Today, the avenue helplessly serves as a major thoroughfare for draining enormous volumes of automobiles and trucks from inside and outside of the city both day and night, and hence completely shuts off the close relationship between the northern and southern portions of the old city.

The Rattanakosin Island Project still exists and a great many problems have yet to be solved. The project area stretches from the walls built during the Thonburi period on the west side of the river to the city walls on the east side. The said boundary is presumably conceived as the core of the old settlements of Bangkok.

The core of old Bangkok on the east side of the Chao Praya river consists of the 'inner' and 'outer' areas as divided by a moat along the demolished walls ${ }^{4}$. The inner area features imperial architecture such as palaces, temples and other buildings of historic significance. The area is highly restricted to any new developments and modification of public buildings. Residents of the three resistant communities on the riverfront, Tha Tien, Tha Chang and Tha Prachan, are living in fear as they are being targeted to be wiped out and replaced with green open spaces.

In the outer area, less significant buildings and sites are scattered all around. The identities of many communities are gradually dying out together with socioeconomic vitality. Without positive guidance and new investments, one can expect a deteriorating environment, eventual decay, and finally the demise of the old city. It is also sad to find that no community participation has been invited in the planning process during the past 30 years.

\section{The old city today}

The following analytical descriptions of the outer area of the old city core are summarized from recent studies, research works, and special reports.

As mentioned earlier, the area under review has been bisected into north and south territories. Bordering the Chao Praya river, most of the land in the northern portion had been allocated to the nobles, a Moslem community, and a couple of Buddhist temples established

\footnotetext{
${ }^{4}$ Some texts refer to the 'outer' part as the 'middle' part, mistakenly annexed the area between the city walls and the third moat excavated during the reign of King Rama IV.
} 
since the founding of the city. This area, commonly called Bang Lampoo, was later developed into a shopping node from where people inside and outside the area came for leather goods, outfit tailoring, and ready-made clothing. A number of modern department stores were developed at a later period to facilitate shoppers. Surprisingly, the area known as Khaosan road has now become a popular hub for international backpackers. Within walking distance, the recent improvement of a historic fort, Phrasumen, on the riverfront to serve as a public park, Santichaiprakarn park, has brought laudable environmental effects to the area. However, strip developments behind the building blocks along Ratchadamnoen Avenue have already turned into slums.

On the other hand, the old settlements with rich diversity in the southern portion of the old city core deserve deeper investigation.

Places of interest for possible improvement were studied and identified by a graduate student of Silpakorn University in 2002. Such places and activities were found to have kept the old city alive with their unique identities as follows:

- Strip of second-hand goods /military outfit and accessories / hiking supplies

- Strip of Buddhist religious goods

- Silversmith/goldsmith/ decorative items such as badges and trophies

- Printing shops

- An old prison converted into a museum and public park

- Shops selling bamboo weaving and rattan/wickerwork products

- Jewelry dealers

- Audio-visual appliances
- Gun and ammunition supply dealers

- A shopping center built on the site of an old market

- A well-preserved theater building of early modern style

- A noble's property once turned into a famous entertainment complex in 1950 s, now converted into retail shops and department stores

- Pedestrian shopping alley linking the Indian and Chinese communities

- Wholesale fresh flower and vegetable markets

The outer area of the old city core has been in decline and thus needs careful study and revolutionary planning as well as visions and positive guidelines to revive its socioeconomic vitality and physical livability.

In 1991, a group of Architecture Faculty members from Chulalongkorn University, in their research project entitled Physical Elements of Rattanakosin City, (Naengnoi and others, 1991) identified the following problems of the said area:

People keep moving out to seek business opportunities and better living environment

The rate of out-migration is higher than that of in-migration due to the deteriorating ambience of the old city and its run-down business is.

The rising cost of land in the height restricted zone has held back investment

\footnotetext{
${ }^{5}$ Ms. Vasinee Visuthiviset's project entitled A Study of Old Bangkok Area to Promote Tourist Routes, implemented to fulfill the requirements of Urban Design Studio 2.
} 
A classic example is the New World Department Store located just opposite a major Buddhist temple in Bang Lampoo. While the maximum height is restricted to four stories, the company gradually added four more floors to the building. With the court's ruling to knock down the top four floors, the company decided to go out of business.

\section{Obsolete regulations and standards to curb and prevent encroachment}

In contrast to the just-mentioned case, historic preservation in the old city still lacks appropriate bylaws for special protection of the national heritage against offensive developments.

\section{Poor quality of tourist-related facilities}

Despite an ever increasing number of tourists visiting the old city each year, there is still no definite plan to deal with critical problems such as inadequate parking for tourist buses, messy services and soliciting street vendors at tourist spots, hazardous pavements and street crossings for pedestrians, missing information signs, unavailable onsite transportation, etc.

\section{Pollution and dull streetscapes}

Water in the canals and other waterways is substandard. Investment in water treatment plants by the Bangkok Metropolis Administration in recent years has yet to yield fruitful results. Furthermore, visitors to the area often find themselves disturbed by low air quality, dust and loud noise generated by road traffic. Except for Ratchadamnoen Avenue, an in-depth study recommends that most streetscapes should be improved.

\section{Conclusion}

Located on a flood plain suitable for agriculture, Bangkok came to public recognition in the early $16^{\text {th }}$ century after a river short-cut was dug through it. Its new role as a check point for ships prevailed until the fall of Ayuthaya in 1767.

The new capital city after Ayuthaya, Thonburi, was founded by King Taksin who reclaimed the independence of the country. Its development was concentrated on the west bank of the Chao Praya river for 15 years. The Temple of Dawn, and King Taksin's palaces and houses along the canals are the legacy of such period.

The city walls on both sides of the river were torn down in 1782 when King Rama I, the founder of the Chakri Dynasty, decided to move the capital across the river to the east because he realized that to extend the palaces and the city limits on the Thonburi side was almost impossible due to limited developable land and erosion problems.

The building of Rattanakosin, the origin of contemporary Bangkok, followed the model of Ayuthaya city. During the first 70 years of development until the end of King Rama III, patterns and styles of the city were influenced by Indian, Chinese and other neighboring cultures. Early city dwellers preferred to live and do business in boathouses and use waterways as their means of transportation. Most buildings during that time were built facing water and significant structures, particularly those built during King Rama III's reign, clearly show the influence of Chinese architecture. As land transportation, only a handful of pathways were built mainly 
for walking. Historic monuments and sites of the city in the early years include the Grand Palace, the Temple of the Emerald Buddha, the City Pillar, the Giant Swing, the Royal Cremation Ground, city walls and other imperial architecture inside the inner city.

The city walls were all demolished in the 1850s when King Rama IV opened the door to Western civilization. The city boundaries were extended far out to the east to relieve overcrowding and Bangkok began to grow in a Western style. The first roads for horse traffic, wagons, and promenading purposes flanked by brick buildings for commercial activities on both sides came on the scene. These trends prevailed and began to replace the water-based lifestyle of Bangkok.

Then came the glorious time and the longest reign of King Rama V the Great who led the nation to liberation and modernization to Western standards. His reign coincided with $20^{\text {th }}$ century industrial technology and the first centennial of Bangkok. Modern infrastructure such as roads, bridges, electricity, telecommunications, trams, railroads, automobiles, etc. was adopted to equip the city in parallel with radical changes in the economic, educational, medical, and administrative systems. Above all, his great legacy for Bangkok is the creation of Ratchadamnoen Avenue linking the Grand Palace to the new Dusit Palace, hence instigating the city's growth to the north-much as King Rama IV's Summer Palace induced growth to the east.

Major physical improvements for Bangkok made King Rama V the most beloved monarch. When he passed away in 1910, his sons, Kings Rama VI and Rama VII, continued on with the same policies and attitudes towards Westernization until the end of absolute monarchy in 1932.

Since the regime change, the areas outside the old city walls were overwhelmed with an influx of immigrants from all over the country. Such incidents have caused chaotic situations which have grown worse since the end of the Second World War. Today, with a number of defunct master plans, weak controls, and lack of serious implementation, Bangkok has much to do to achieve livability and an acceptale quality of life for its ten million inhabitants.

Despite the adoption of Rattanakosin Island Project in the early 1970s, governments over the past 30 years have achieved very little in terms of benefiting the people. Negative controls and a lack of community participation have played a critical role in bringing stagnant situations to the old city where business and commercial activities have shown signs of degeneration. Recent studies and scholastic researche have indicated the need for positive guidance and appropriate action in order to bring back the vibrancy and livability of the old settlements. 


\section{References}

Department of Town Planning. City Planning Movement during the Reign of King Rama IX. Ministry of Interior.1999.

Kamthorn Kulachol and Songsan Nilkamhaeng. Physical Development of the Bangkok City Since Its Inception up to 1932. Silpakorn University Journal, Special Issue. Vol.4-5. December 1982.
Naengnoi Saksi and Others. Research on

Physical Elements of Rattanakosin City. Chulalongkorn University. 1991.

Suárez, Thomas. Early Mapping of Southeast Asia. Hong Kong : Periplus Editions.1999. 


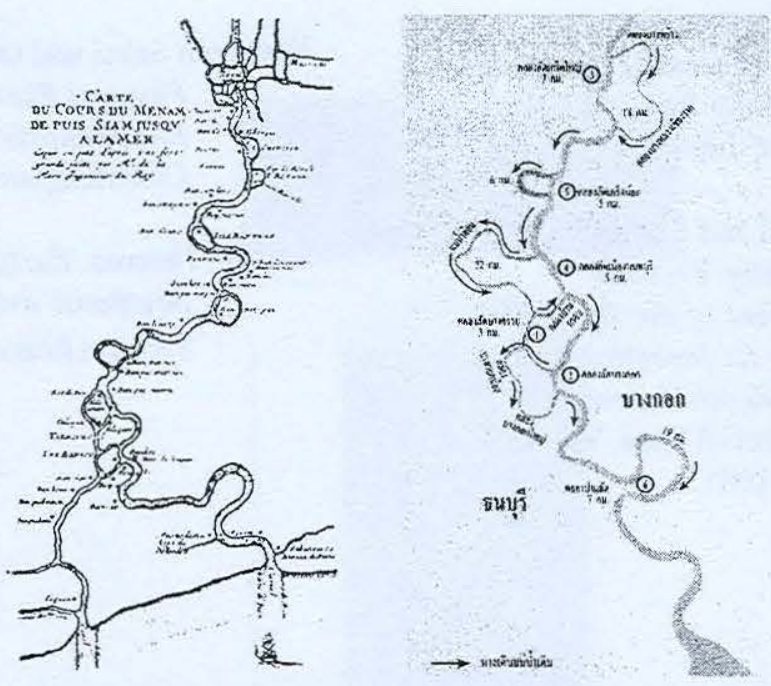

\section{Shortcuts along the Chao Praya river} during 1534 - 1546 A.D.(Ayuthaya period)

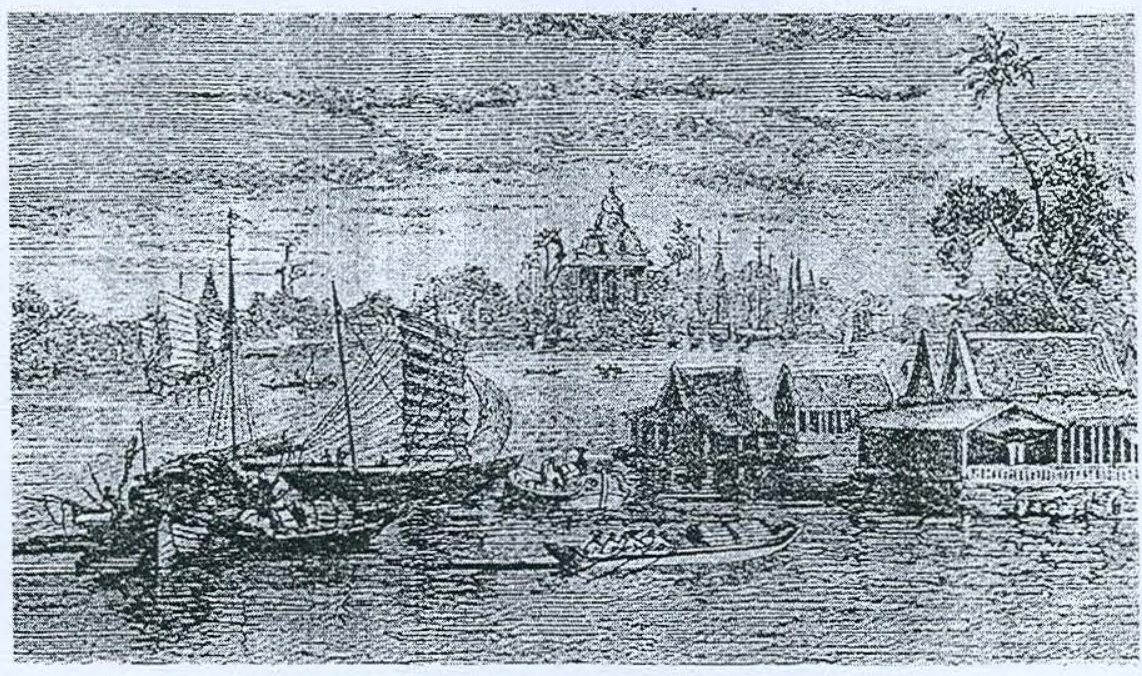

2. Bangkok served as a checkpoint for more than 200 years 

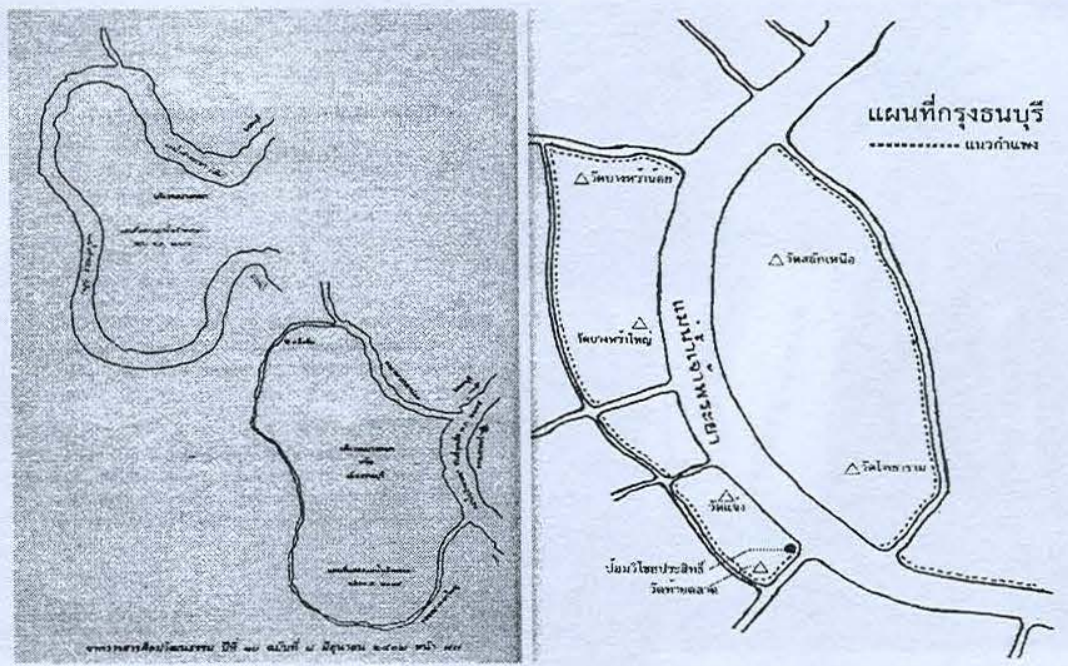

\section{Location of Bangkok and Thonburi}

Built-up areas were concentrated on the west side and sparse settlements of minority groups on the east
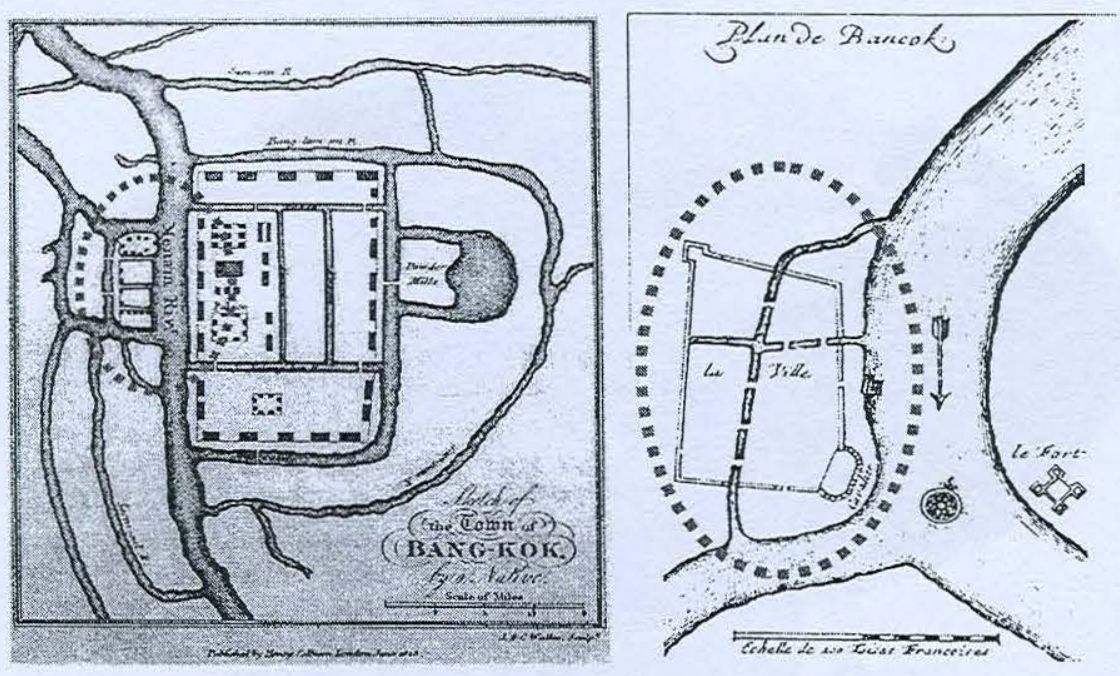

4. Early maps of Thonburi as a new capital

Drawn by a native and a westerner 


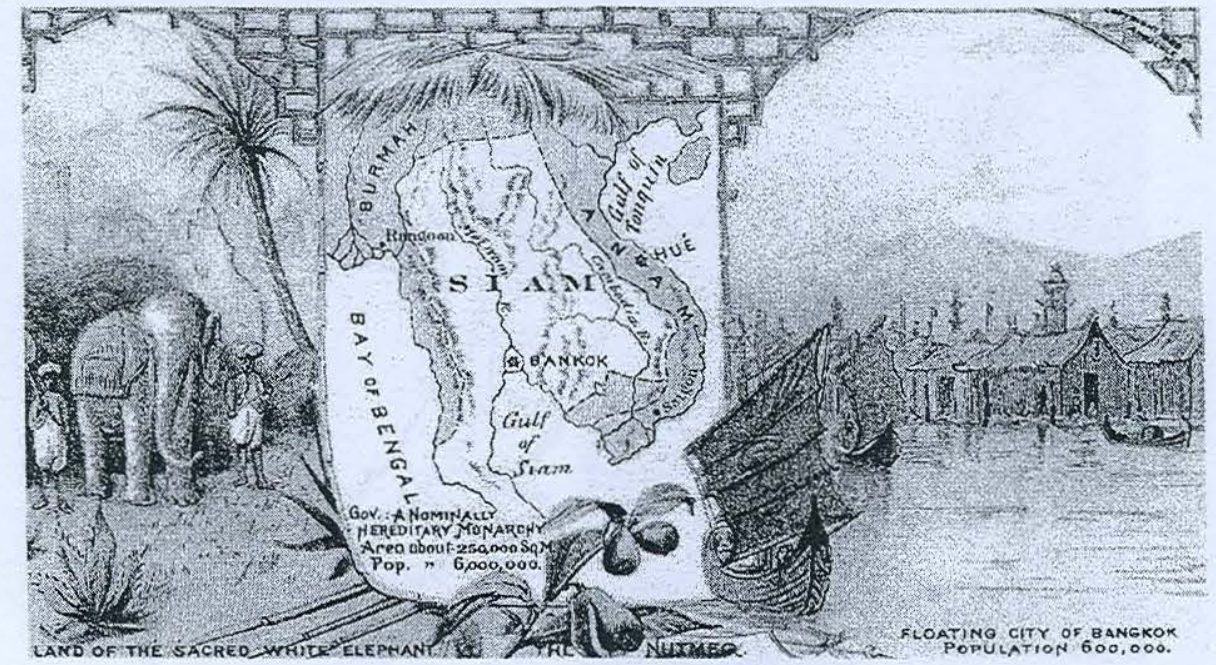

5. White elephant \& Floating city

The images of Siam and Bangkok

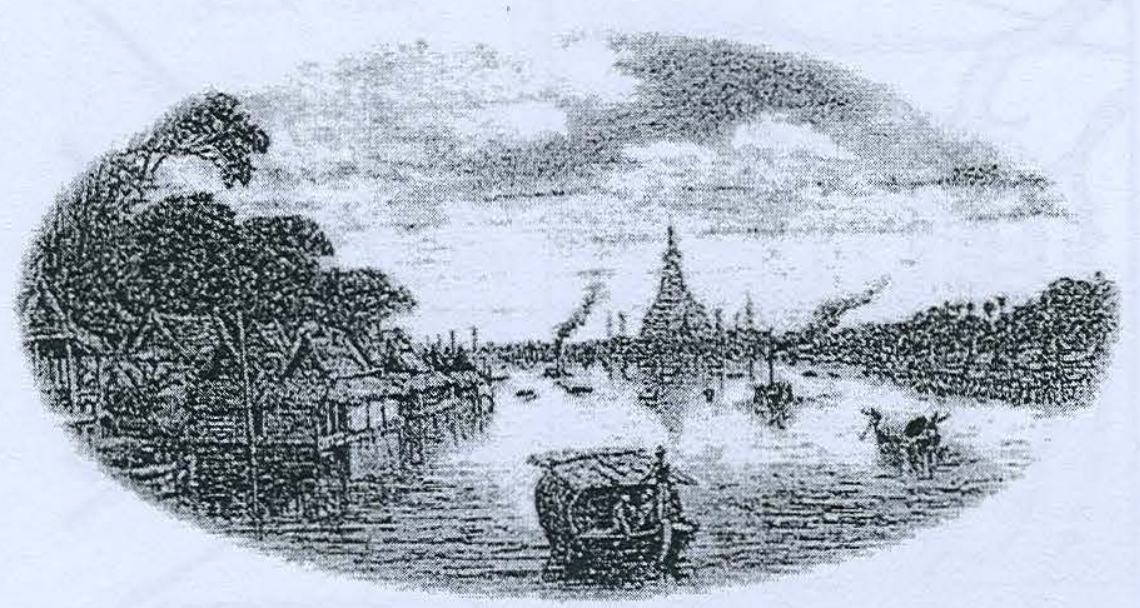

6. Boathouses \& Temple of Dawn

Early symbols of Bangkok 

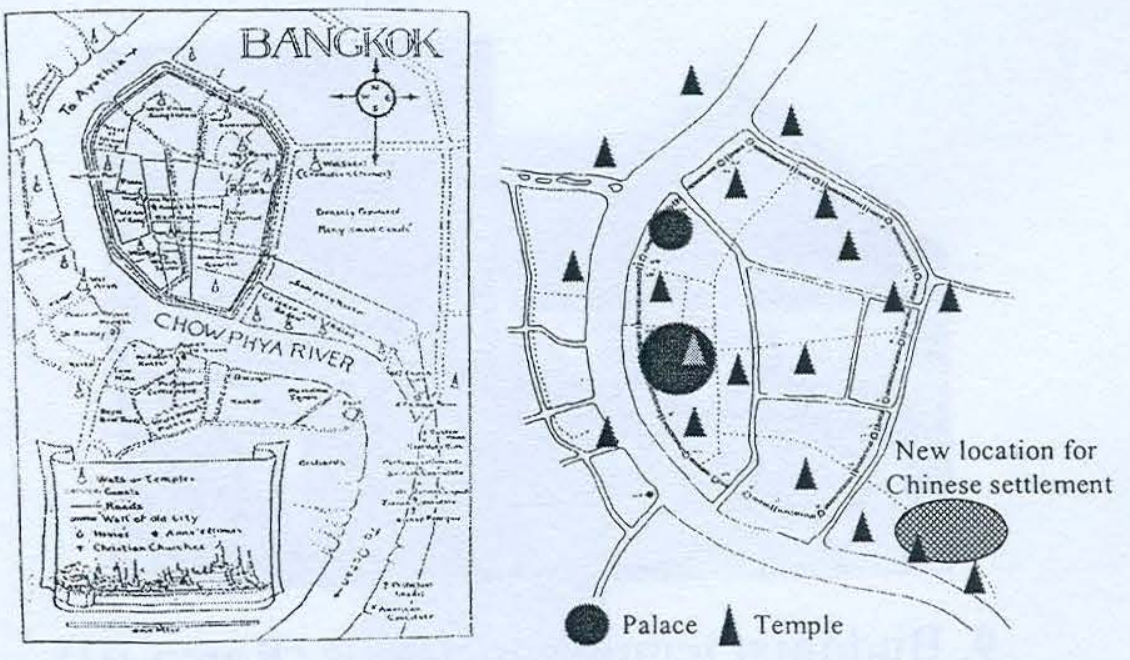

7. Rattanakosin as a walled city $1782-1851$ 70 years of development (Kings Rama I - Rama III)

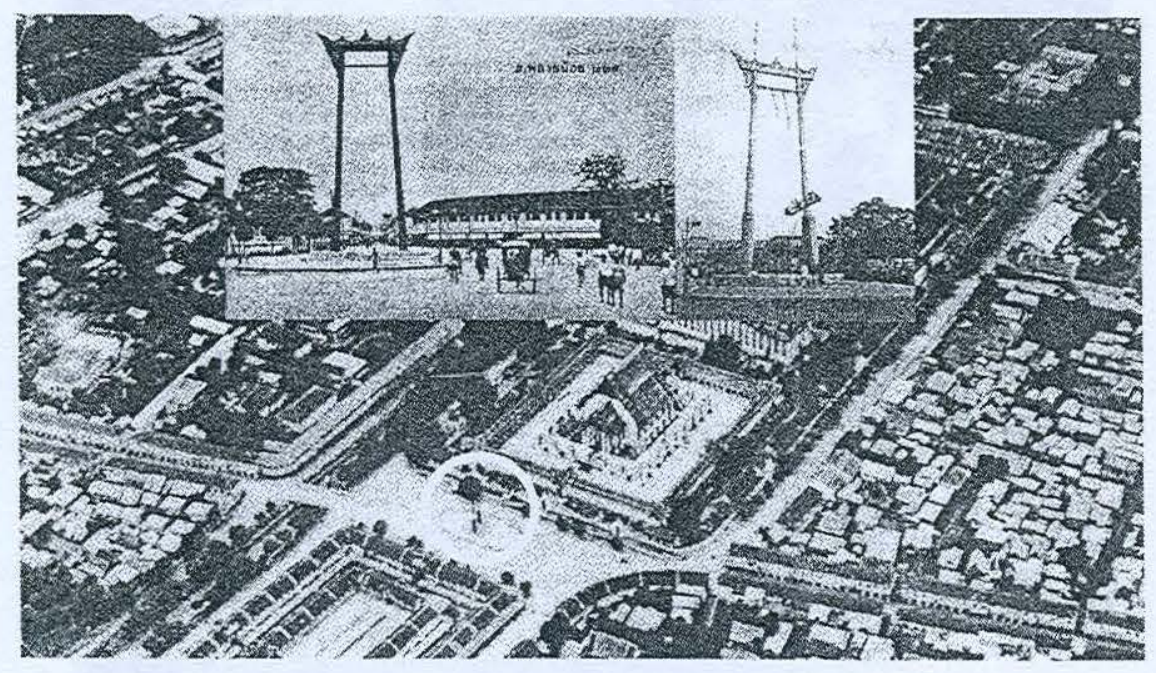

8. Giant swing \& Brahman quarters

Influence of Hinduism in a new Buddhist city 

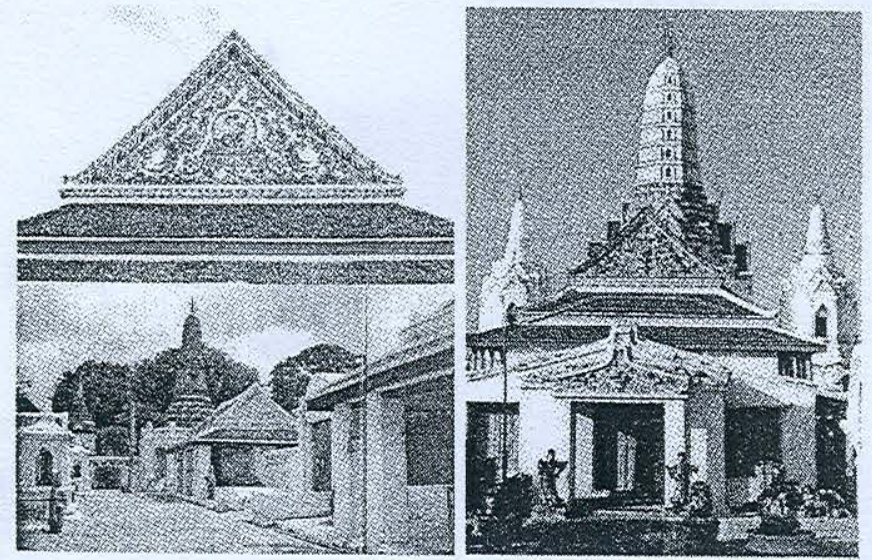

9. Buddhist temples in 1800 s (Rama III)

Showing strong influences of Chinese style

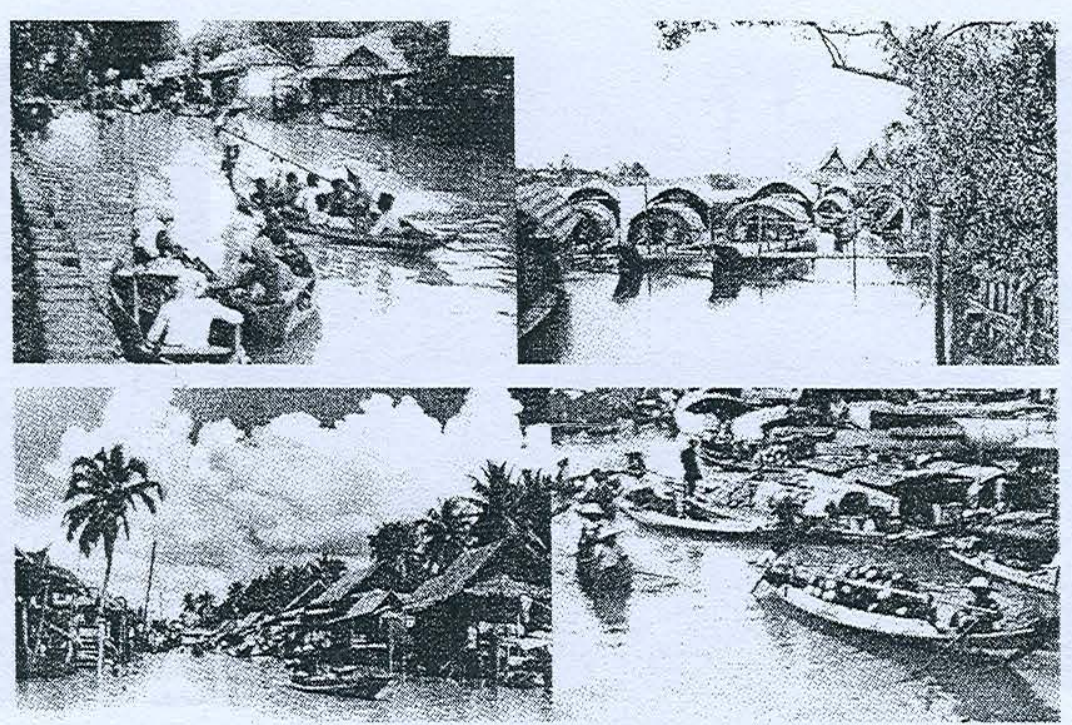

10. Living and traveling on waterways

Early Bangkok way of life 

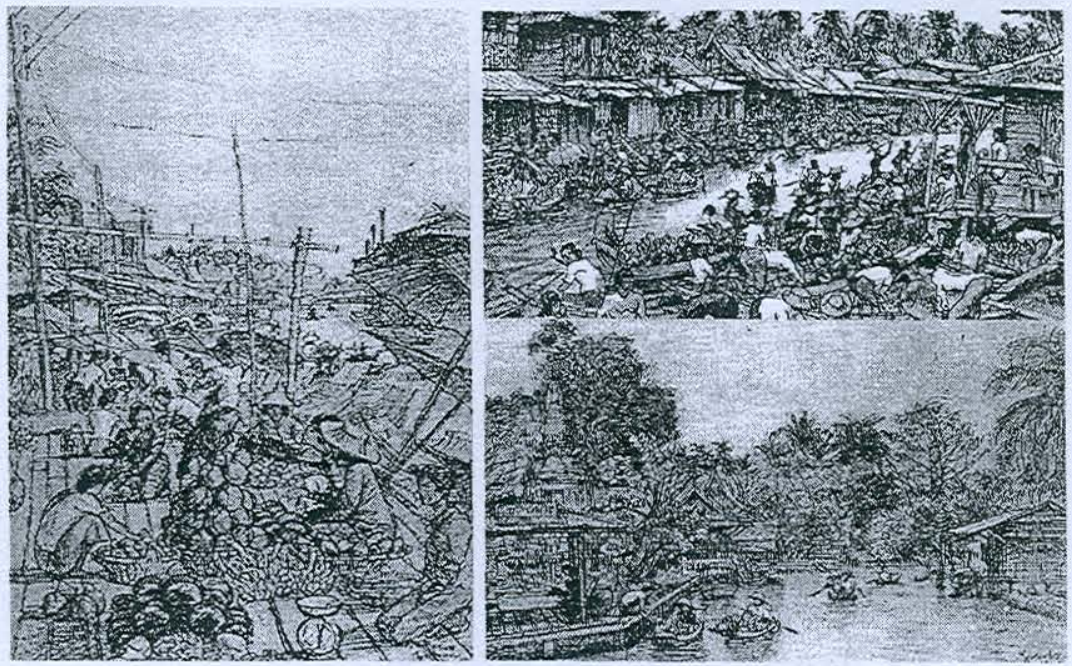

\section{Venice of the East}

Impressions in water color by a Japanese artist, Niro Yokota
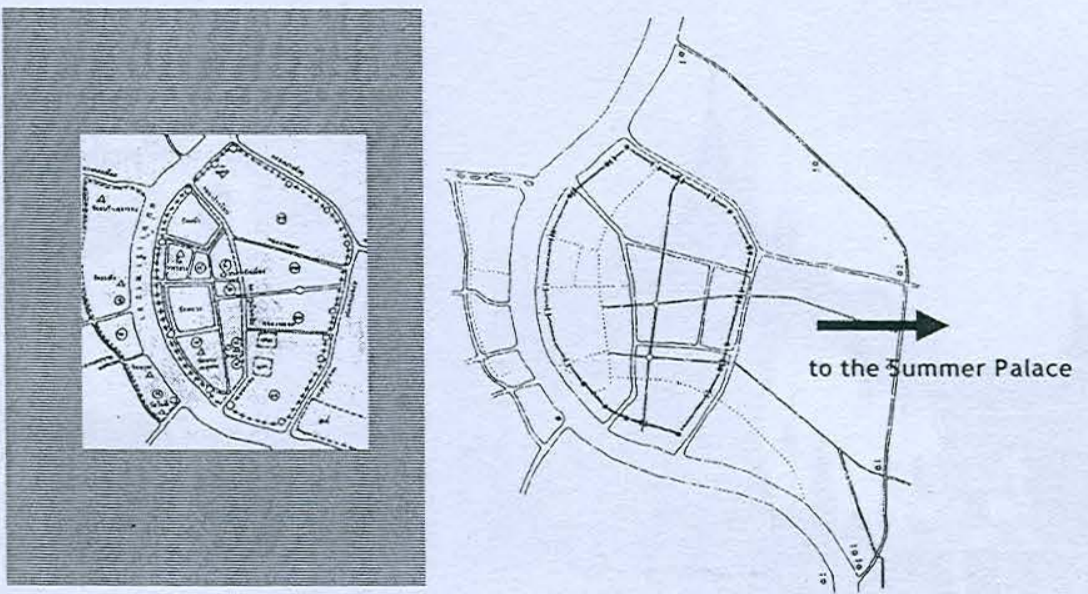

12. King Rama IV demolished city walls

To solve overcrowding and extend the city to the east 


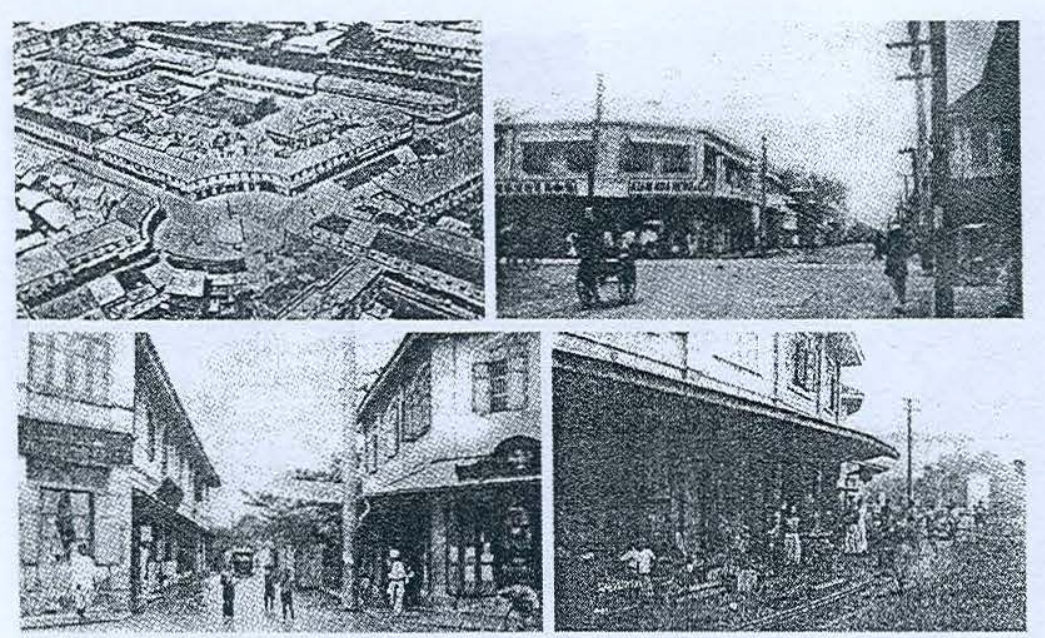

\section{Beginning of land settlement}

Early roads were enclosed by rows of shophouses
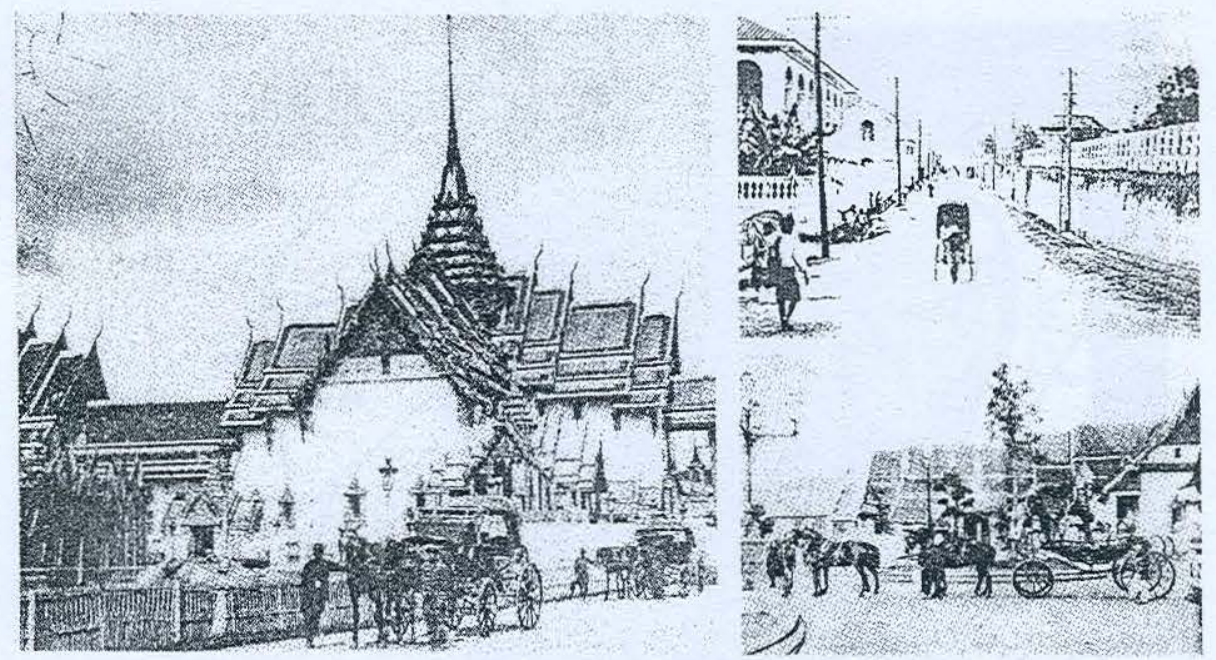

14. Facilities for emerging land transportation

Roads were built for carts and carriages as well as promenading 

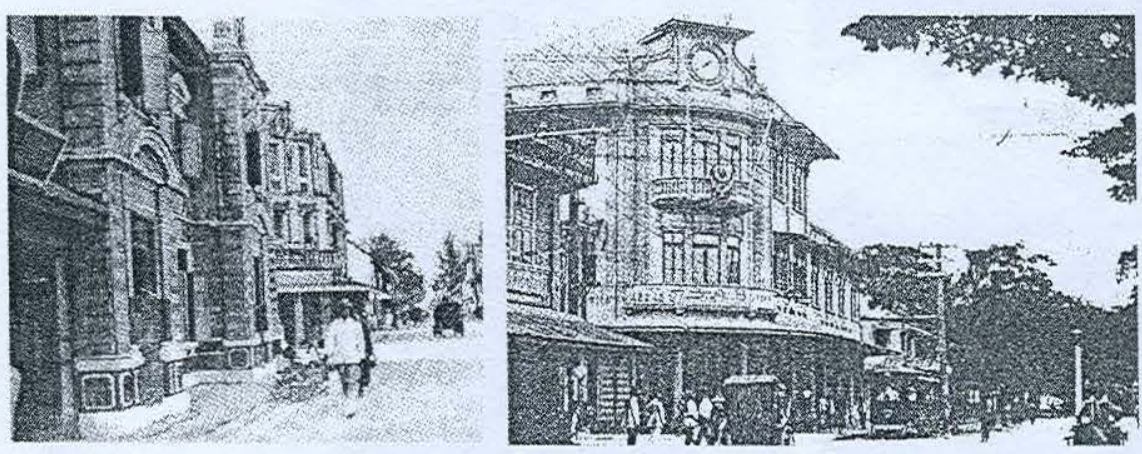

15. Westernization by the end of 19 th century Hustle and bustle districts in the south of Bangkok

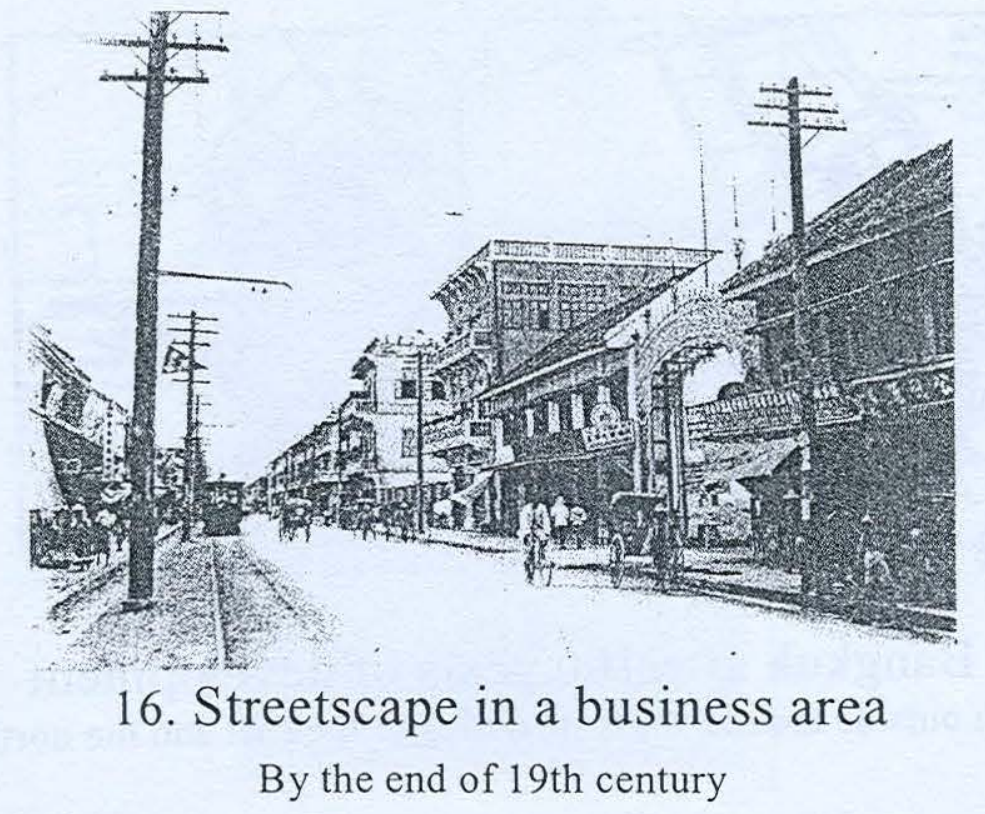



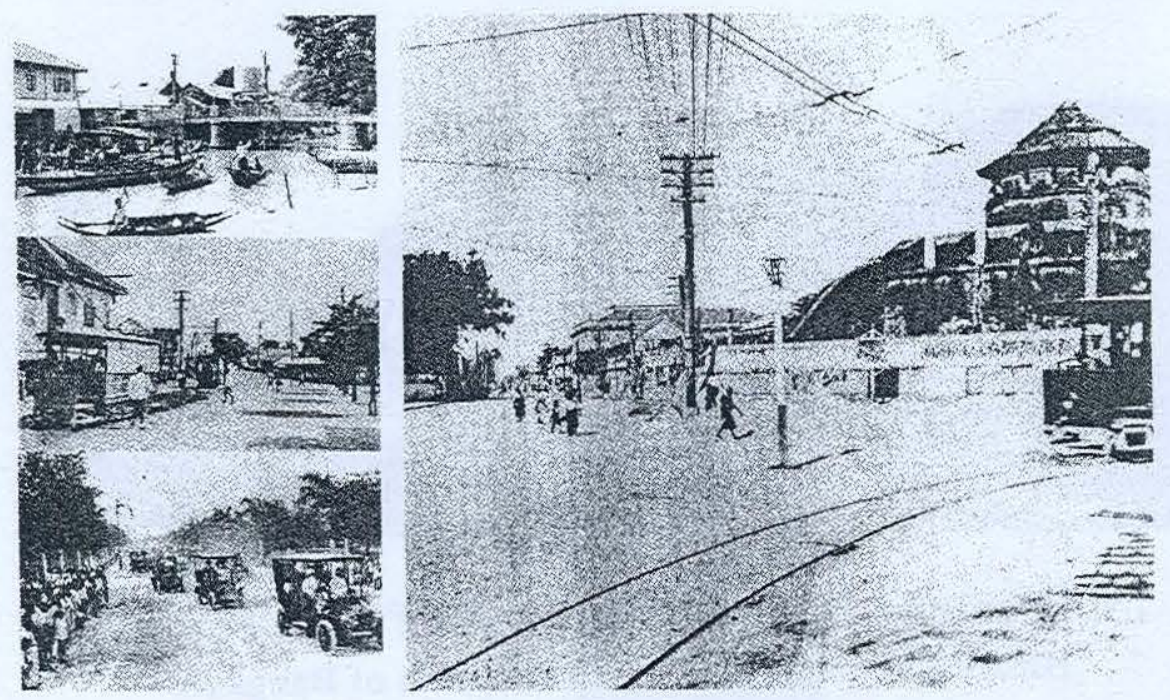

17. Influx of the 20th-century technologies

Bangkok was equipped with modern infrastructures
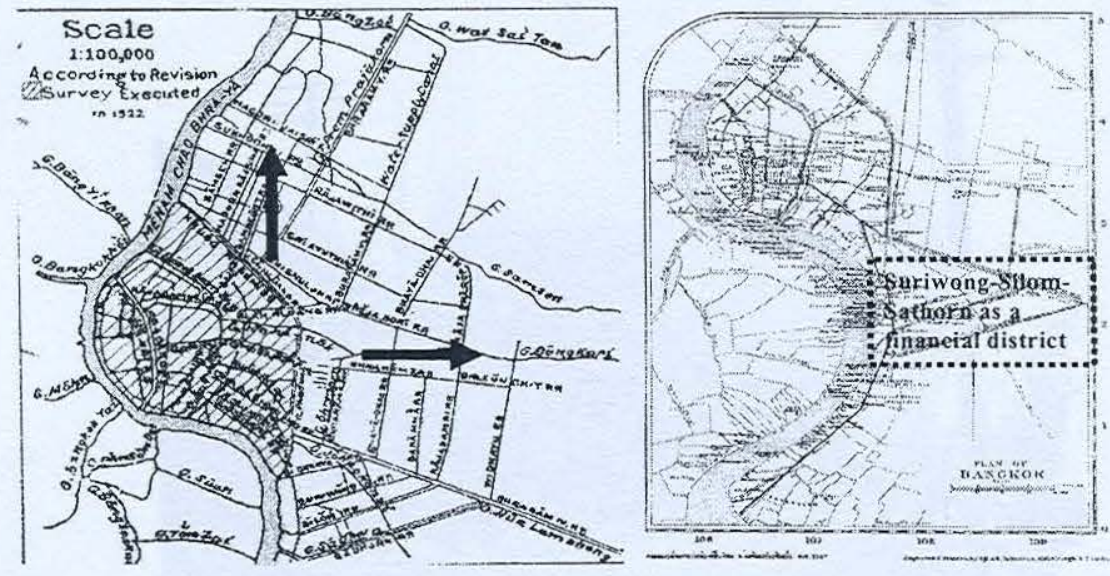

18. Bangkok after100 years of development

Growth outside the old walls spreading to the east and the north 

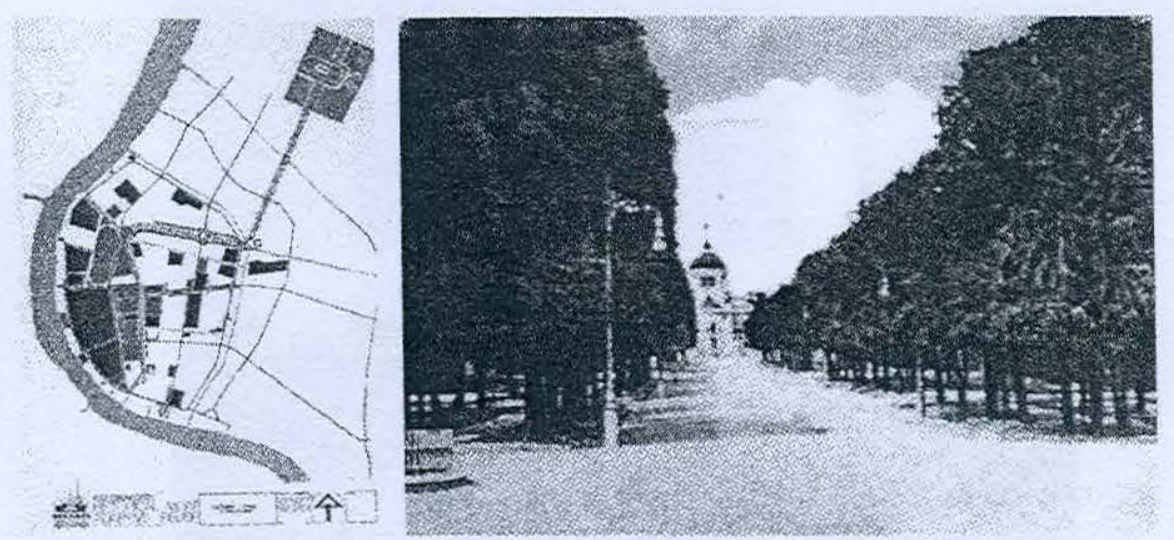

19. King Rama V's city beautification

Dusit Palace \& Ratchadamnoen Avenue (1899-1903)
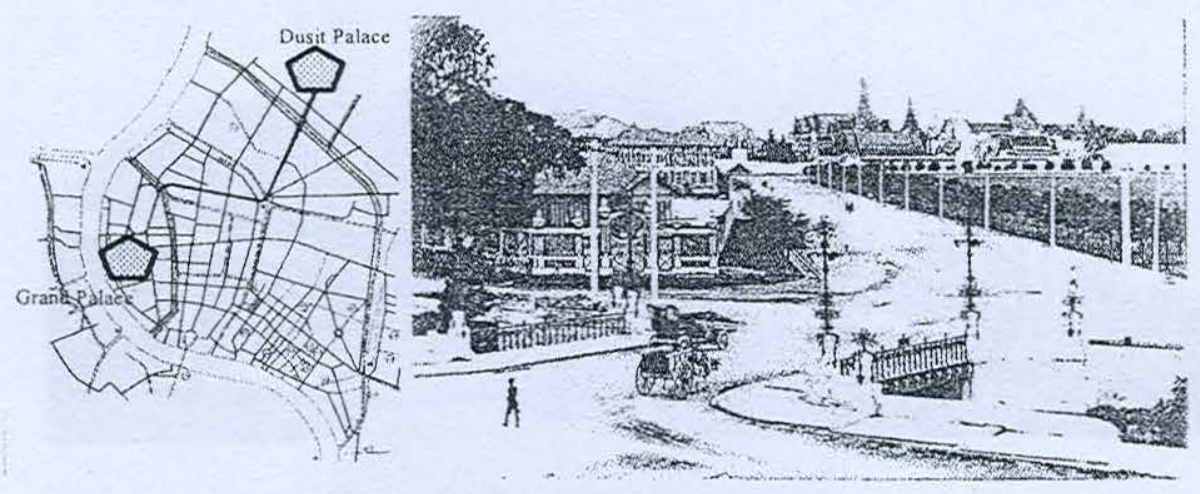

20. King Rama V's city beautification

Ratchadamnoen Avenue was purposely linked to the Grand Palace 


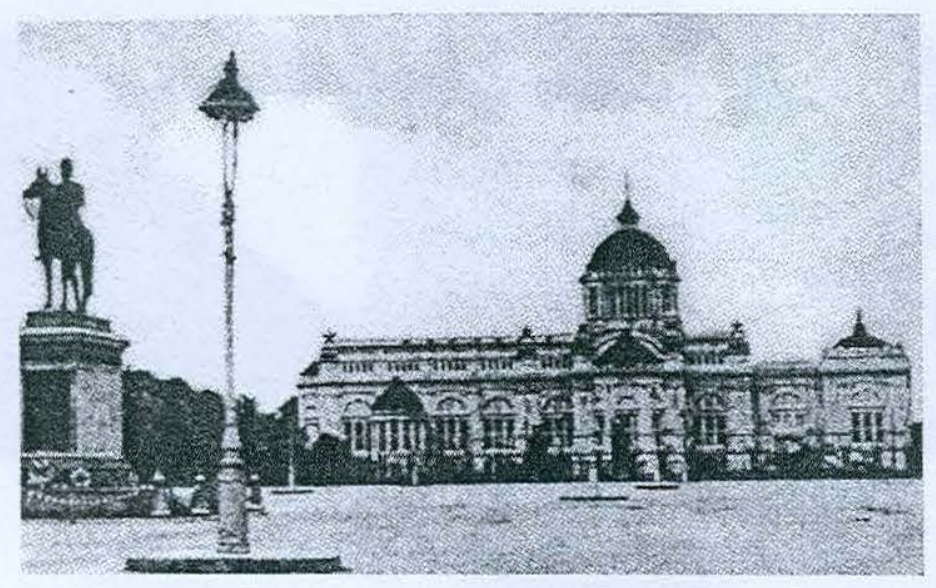

21. King Rama V's equestrian statue

In front of the Dusit Palace and the Royal Plaza

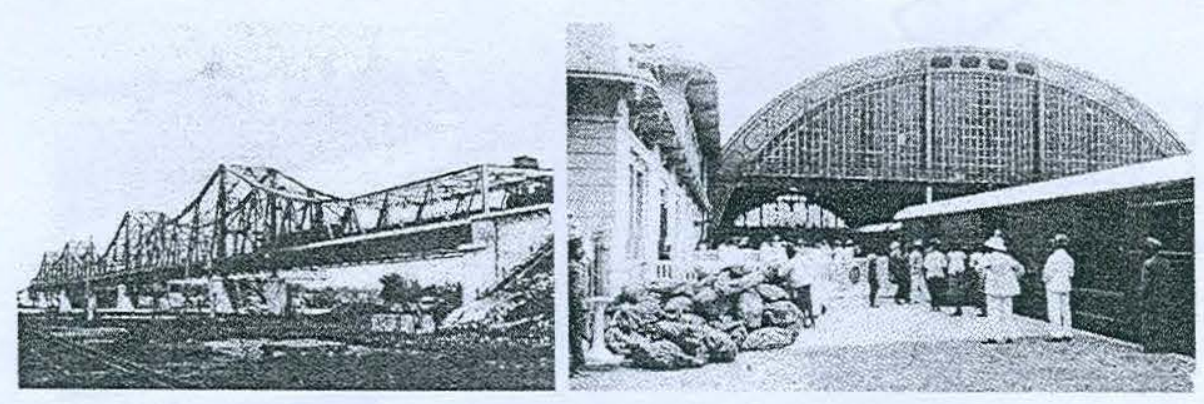

22. Pending projects completed by King Rama VI

First bridge across the river \& railway terminal (duringWW. I) 


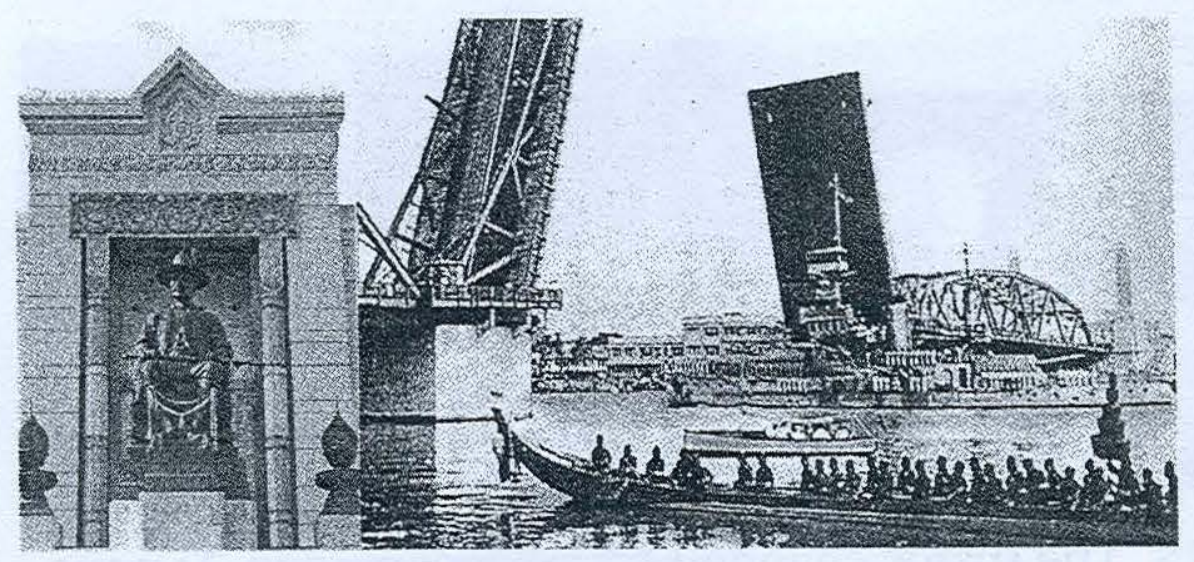

\section{King Rama VII and regime change in 1932}

Bangkok's celebration of its $150^{\text {th }}$ anniversary

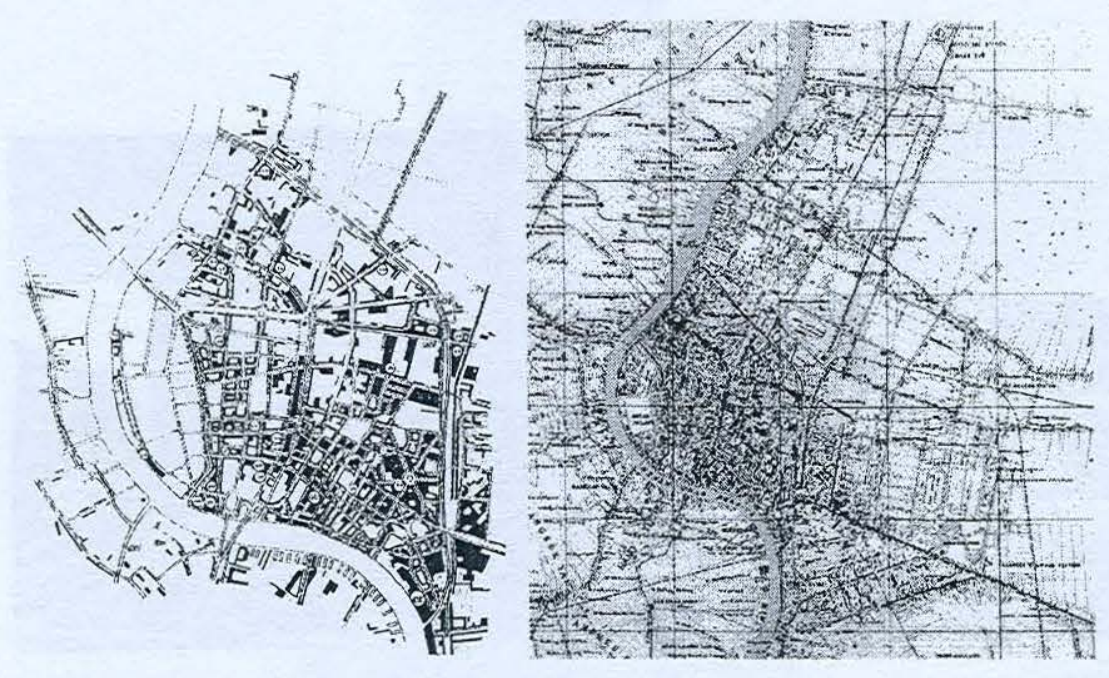

24. The city's growth after regime change

Bangkok is packed with settlers from the provinces 

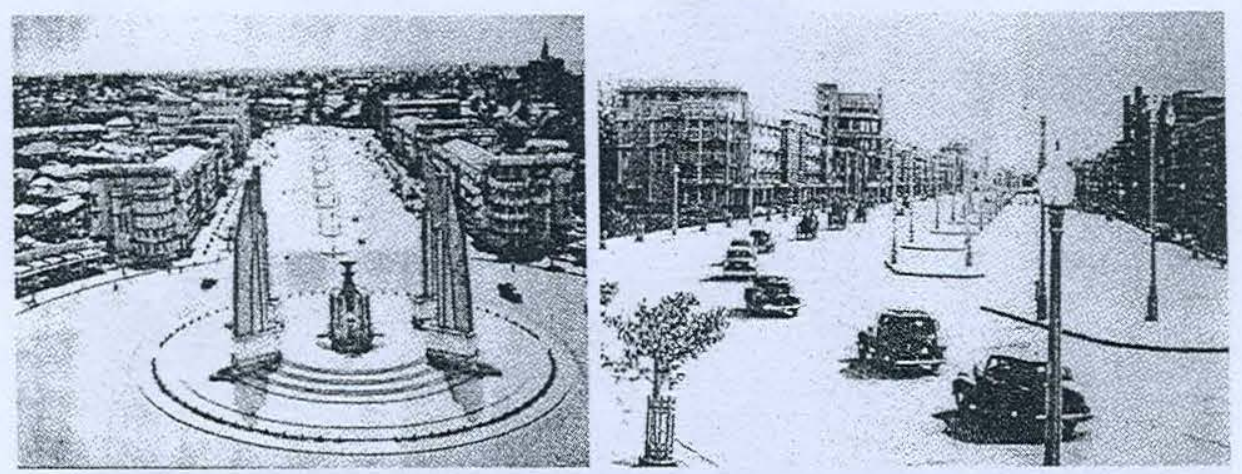

25. The major change of Ratchadamnoen Avenue Borrowing from the model of the Arc de Triomphe \& the ChampsÉlysées

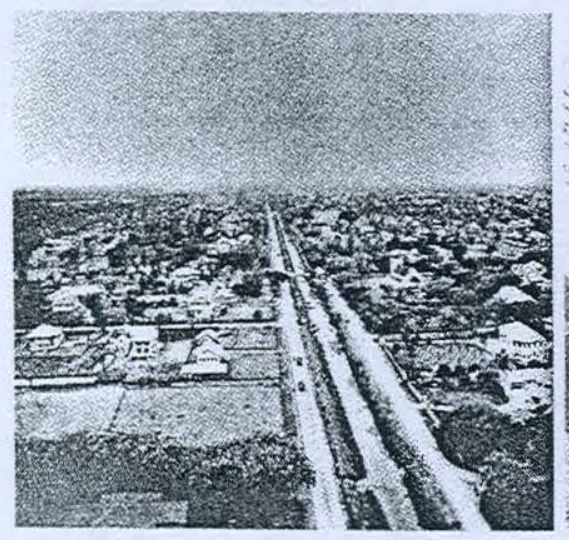

Before

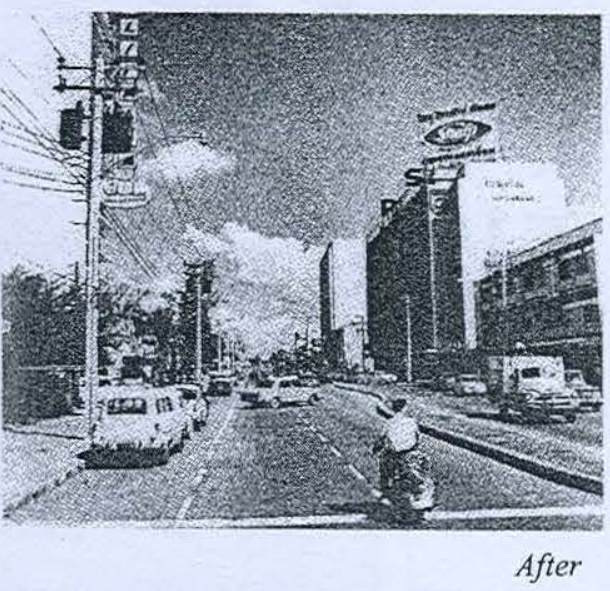

After

26. After the Second World War

Sathorn \& Silom areas lost their canals 

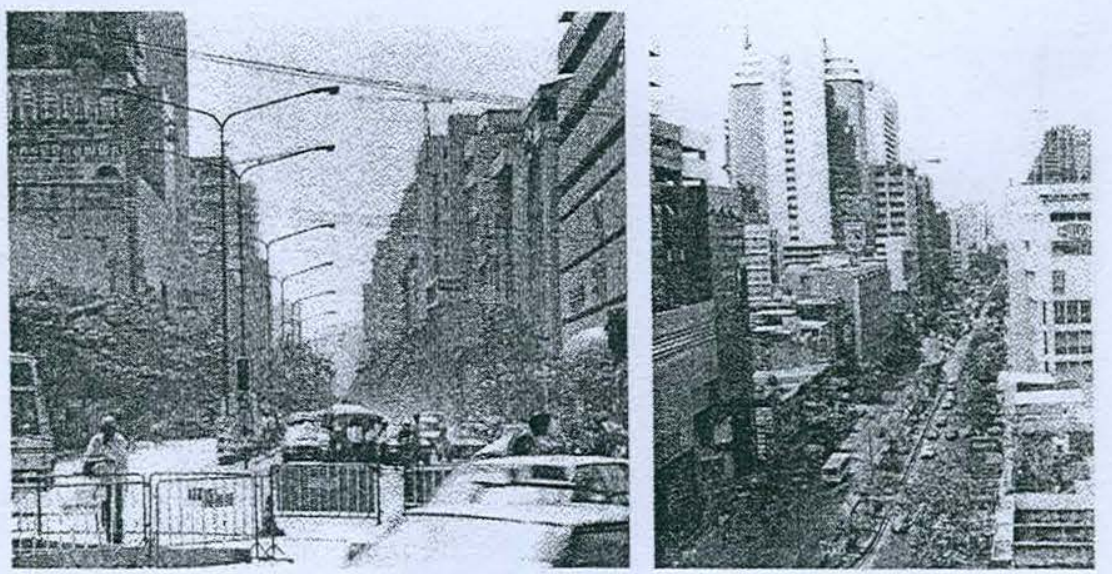

\section{Since the Second World War}

Silom has turned into a bustling financial district

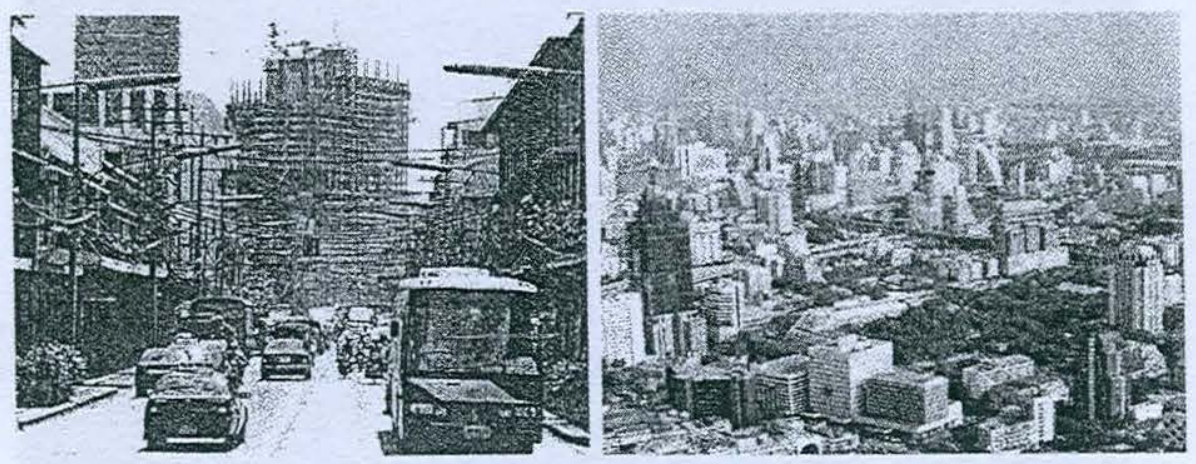

28. Bangkok becomes a fast growing metropolis

The rate of urbanization is overwhelming 


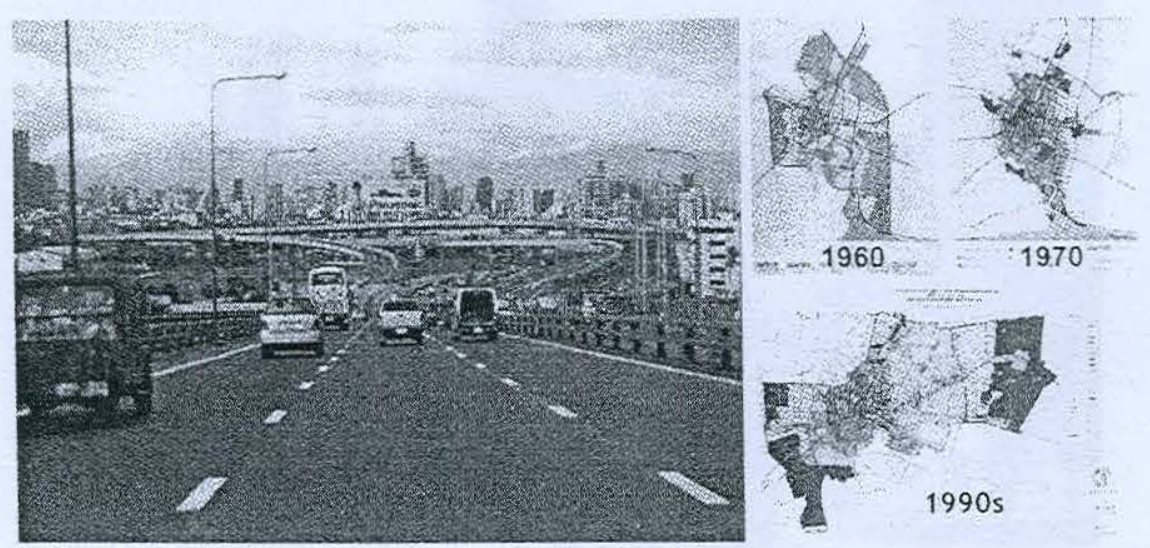

29. Bangkok today keeps growing recklessly

Despite a number of master plans
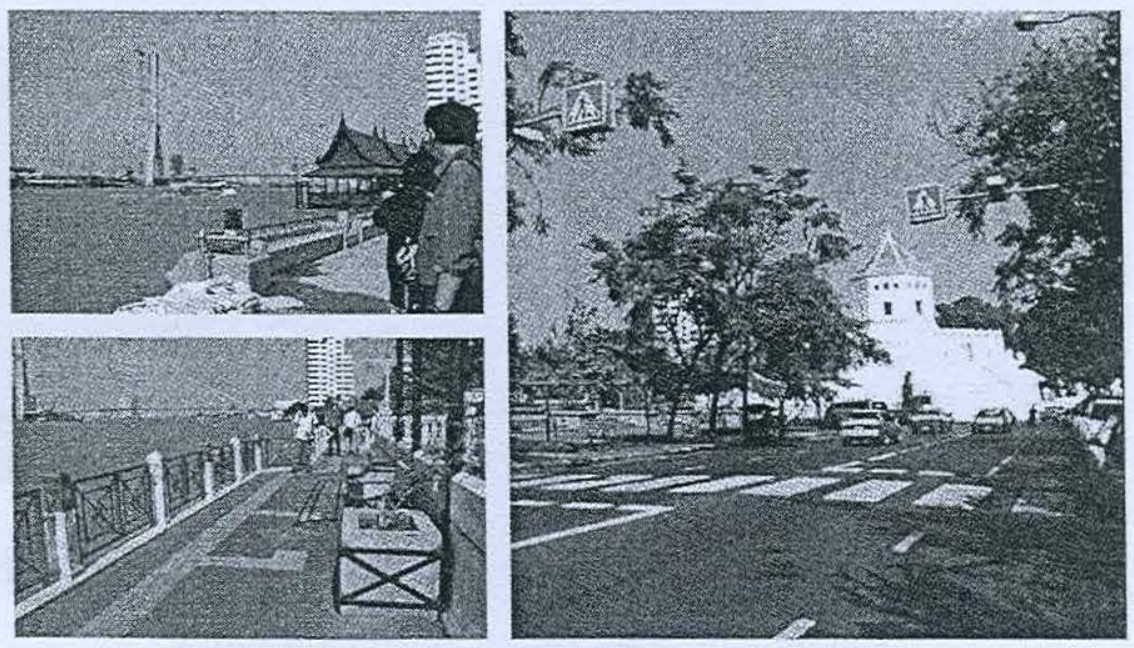

30. Preservation of the old city

A fort by the river was recently converted into a public park 